\title{
HB-EGF Is a Promising Therapeutic Target for Lung Cancer with Secondary Mutation of EGFR ${ }^{T 790 M}$
}

\author{
FUSANORI YOTSUMOTO ${ }^{1 *}$, SATOSHI FUKAGAWA ${ }^{1,2^{*}}$, KOHEI MIYATA $^{1}$, SUNG OUK NAM $^{1}$, \\ TAKAHIRO KATSUDA ${ }^{1}$, DAISUKE MIYAHARA ${ }^{1}$, TAKASHI ODAWARA ${ }^{3}$, SADAO MANABE ${ }^{3}$, \\ TOYOKAZU ISHIKAWA ${ }^{3}$, SHIN'ICHIRO YASUNAGA ${ }^{2,4}$ and SHINGO MIYAMOTO ${ }^{1}$ \\ Departments of ${ }^{1}$ Obstetrics and Gynecology, and ${ }^{4}$ Biochemistry, and \\ ${ }^{2}$ Central Research Institute for Advanced Molecular Medicine, \\ Faculty of Medicine, Fukuoka University, Fukuoka, Japan; \\ ${ }^{3}$ Kanonji Institute, Research Foundation for Microbial Diseases of Osaka University, Kagawa, Japan
}

\begin{abstract}
Advanced lung cancer is one of the most lethal malignancies. Many anticancer agents have been developed for lung cancer with epidermal growth factor receptor (EGFR) mutations, but its prognosis remains extremely poor. The development of molecularly-targeted therapies is required for patients with lung cancer with secondary mutation of the EGFR gene. In this study, in order to assess the validity of heparin-binding EGF-like growth factor (HB-EGF) as a therapeutic target for lung cancer with EGFR mutation, we examined the antitumor effects of a specific inhibitor (cross-reacting material 197; CRM197) on lung cancer cells with EGFR mutation. HBEGF was the most predominantly expressed EGFR ligand in lung cancer cells with EGFR mutation. CRM197 induced significant cell apoptosis and marked suppression of tumorigenicity in lung cancer cells with single or double mutation of EGFR. These results suggest that HB-EGF is a rational target for the treatment of lung cancer with EGFR mutation.
\end{abstract}

This article is freely accessible online.

\footnotetext{
*These Authors contributed equally to this study.

Correspondence to: Dr. Fusanori Yotsumoto, MD, Ph.D., Department of Obstetrics and Gynecology, Faculty of Medicine, Fukuoka University, 7-45-1 Jonan-ku, Fukuoka, 814-0180. Japan. Tel: +81928011011 ext. 3505, Fax: +81 928654114, e-mail: yotsumoto@cis.fukuoka-u.ac.jp and Dr. Shingo Miyamoto, MD, Ph.D., Department of Obstetrics and Gynecology, Faculty of Medicine, Fukuoka University, 7-45-1 Jonan-ku, Fukuoka, 8140180. Japan. Tel: +81928011011 ext. 3505, Fax: +81 928654114, e-mail: smiya@cis.fukuoka-u.ac.jp
}

Key Words: HB-EGF, EGFR mutation L858 T790M, lung cancer.
Lung cancer is the most common cancer and remains the leading cause of cancer-related deaths worldwide. In total, $85 \%$ of lung cancer cases are non-small cell lung cancer, (NSCLC) and $15 \%$ are small cell lung cancers (SCLC). More than half of patients who were diagnosed with NSCLC at an advanced stage have an extremely poor prognosis; median overall survival is less than 12 months and 5-year survival is less than $1 \%$ despite advances in chemotherapy $(1,2)$.

NSCLC encompasses the pathologically distinct adenocarcinoma, squamous cell carcinoma, and large cell carcinoma sub-types. Approximately $45 \%$ and $40 \%$ of patients with NSCLC are positive for epidermal growth factor receptor (EGFR) exon 19 deletions and exon 21 L858R mutations, respectively $(3,4)$. These mutations are predictive of treatment benefit from small molecule EGFR tyrosine kinase inhibitors (TKIs) such as erlotinib, gefitinib, and afatinib. In addition, such sensitizing EGFR mutations occur in approximately $10 \%$ of Caucasian patients and more than $50 \%$ of Asian patients with NSCLC (5). However, most patients develop resistance to these small-molecule EGFR TKIs after the first 8 to 16 months (6). T790M in EGFR is an acquired resistance mutation in $60-70 \%$ of patients who initially respond to prior treatment with small-molecule EGFR TKIs (6). On the basis of these lines of evidence, the development of molecularlytargeted therapies is required to ameliorate the clinical prognosis in NSCLC with T790M mutation.

Heparin-binding EGF-like growth factor (HB-EGF) is an EGFR ligand (7-9), and is initially synthesized as a transmembrane protein, similarly to other members of the EGF family of growth factors (7-9) Previously, we reported that RNA interference of proHB-EGF $(H B E G F)$ gene, or the addition of cross-reacting material 197 (CRM197), a specific HB-EGF inhibitor, resulted in significant apoptosis of cancer cells harboring HB-EGF expression, indicating that HB-EGF could be a valid target for cancer therapy in ovarian, breast, bladder, and gastric cancer, among others 
(10-12). However, there was no enhancement of expression of any EGFR ligand in lung cancer without mutations. It is therefore plausible that not only EGFR, but also EGFR ligands, could be considered as therapeutic targets in lung cancer with EGFR mutation.

In order to investigate the antitumor effect of CRM197 in lung cancer with EGFR mutation, we examined the expression of EGFR ligands, cell apoptosis and tumorigenicity following gefitinib or CRM197 treatment of lung cancer cells with and without EGFR mutations.

\section{Materials and Methods}

Reagents and antibodies. Cross-reacting material 197 (CRM197) and gefitinib were kindly provided by Professor Eisuke Mekada (Department of Cell Biology, Osaka University, Osaka, Japan) and by AstraZeneca K.K. (Osaka, Japan), respectively.

Cell culture. NCI-H460. A549, NIC-H441, RERF-LC-A1, PC-14, and NCI-H1975 cell lines were purchased from the American Type Culture Collection (Manassas, VA, USA). NCI-H460. A549, and NIC-H441 cells have no EGFR mutations, whereas RERF-LC-A1, PC-14, and NCI-H1975 have mutations in EGFR at L858R, exon 19 deletion (746-750), and L858R plus T790M, respectively. All cell lines were maintained in RPMI1640 medium supplemented with $10 \%$ fetal bovine serum (FBS; ICN Biomedicals, Irvine, CA, USA), $100 \mathrm{U} / \mathrm{ml}$ of penicillin $\mathrm{G}$ and $100 \mu \mathrm{g} / \mathrm{ml}$ of streptomycin (Invitrogen Corp., Carlsbad, CA, USA) in a humidified atmosphere of $5 \% \mathrm{CO}_{2}$ at $37^{\circ} \mathrm{C}$.

Real-time quantitative polymerase chain reaction $(P C R)$ analysis of EGFR ligands. RNA extraction and cDNA synthesis were performed using TRIzol and SuperScript II reverse transcriptase (Invitrogen Corp.), respectively, according to the manufacturer's protocols. The primer and probe sequences for $E G F$ and epigen were as follows: $E G F$ forward primer, 50-CTT TGC CTT GCT CTG TCA CAG T-30; EGF reverse primer, 50-AAT ACC TGA CAC CCT TAT GAC AAA TTT-30; $E G F$ probe, 50-AAG TCA GCC AGA GCA GGG CTG TTA AAC TCT-30; epigen forward primer, 50-TCT ATC TTT TAT TCA ACG CAA TGA CA-30; epigen reverse primer, 50-GGG CTG TGA TTG GAG GTG TT-30; epigen probe, 50-ACT GAC CGA AGA GGC AGC CGT GAC T30. Glyceraldehyde-3-phosphate dehydrogenase $(G A P D H)$ was detected with Assays-on-Demand primer and probe sets Hs99999905_m1 (Applied Biosystems, Foster City, CA, USA). The procedures used for TaqMan quantitative real-time PCR analyses, as well as the sequences of the oligonucleotide primer pairs, TaqMan probes for HB-EGF, amphiregulin, transforming growth factor alpha, epiregulin and betacellulin, and the calculation for mRNA expression index (EI), have been described previously (13). All experiments were carried out independently three times.

Cell apoptosis assay. Extracellular matrix components were removed by detaching cells with trypsin-EDTA and then allowing them to recover for $30 \mathrm{~min}$ in RPMI-640 with $10 \%$ FBS (14). In order to assess the pharmacological effects of gefitinib or CRM197 on cell apoptosis, after rinsing with serum-free medium, cells were incubated in fresh serum-free medium at $37^{\circ} \mathrm{C}$ for $30 \mathrm{~min}$ before seeding $\left(1 \times 10^{6}\right)$ on polylysine-coated $6-\mathrm{cm}$ dishes. Samples were incubated with serum-free RPMI 1640 at $37^{\circ} \mathrm{C}$ for $1 \mathrm{~h}$ to allow complete adherence of cells, and then incubated with serum-free RPMI-1640 plus different concentrations of gefitinib or $1 \mu \mathrm{g} / \mathrm{ml}$ of CRM197 at $37^{\circ} \mathrm{C}$ for $48 \mathrm{~h}$. After these procedures, cells were harvested, pooled, and fixed with $4 \%$ paraformaldehyde at $4^{\circ} \mathrm{C}$ for $30 \mathrm{~min}$ and resuspended in $70 \%$ ethanol at $-20^{\circ} \mathrm{C}$ for $30 \mathrm{~min}$. After washing in phosphate-buffered saline (PBS), the cells were incubated with terminal deoxynucleotidyl transferase (TdT) reaction reagent (MEBSTAIN Apoptosis Kit Direct; MBL Co. Ltd., Nagoya, Japan) for $1 \mathrm{~h}$ at $37^{\circ} \mathrm{C}$, according to the manufacturer's instructions. TdT-mediated 2'-deoxyuridine,-5'-triphosphate (dUTP) nick end labeling (TUNEL)-positive cells were quantified as apoptotic cells by flow cytometric analysis using a FACScalibur (BectonDickinson, Franklin Lakes, NJ, USA).

Tumor growth in nude mice. Subconfluent cell cultures were detached from plates with trypsin-EDTA. A total volume of $250 \mu \mathrm{l}$ containing $5 \times 10^{6}$ cells suspended in serum-free RPMI-1640 was injected into female BALB/c nu/nu mice at 5 weeks of age (Charles River Laboratories). Injected mice were examined every week for tumor apparition. Tumor volume was calculated as described previously (15). In order to assess the effect of inhibition by CRM197, CRM197 dissolved in $1 \mathrm{ml}$ of $20 \mathrm{mM}$ HEPES and $0.15 \mathrm{M} \mathrm{NaCl}$ (pH 7.2) (1 mg) was injected intraperitoneally into tumor-bearing mice. One week after subcutaneous injection of RERF-LC-A1 and NCI-H1975 cells, $1 \mathrm{mg} / \mathrm{kg}$ of CRM197 was administered daily for 10 consecutive days during the course of the treatment. The animal protocol was approved by the guidelines of Animal Care of Fukuoka University (Approval No. 1106482) and Ethics Committee. Animals were observed on a daily bases. Humane endpoints were defined as a loss of more than $10 \%$ of body mass, a tumor greater than $20 \mathrm{~mm}$, or inability to ambulate or rise for food and water. If animals reached these endpoints they were euthanized by exsanguination. Animal surgery and euthanasia using decapitation were performed under inhalation (isoflurane) anesthesia, and all efforts were made to minimize suffering.

Statistical analysis. Data were analyzed using the Mann-Whitney $U$-test. A value of $p<0.05$ was considered statistically significant. Data for many of the experiments were analyzed using Tukey HSD test; statistical significance was also set at $p<0.05$.

\section{Results}

Characterization of lung cancer cells. In order to identify molecular features in lung cancer, we examined the expression of each EGFR ligand in several lung cancer cell lines using RT-PCR. Lung cancer cells with EGFR mutation (RERF-LC-A1, PC-14 and NCI-H1975) had markedly higher expression of each EGFR ligand, compared to lung cancer cell lines without EGFR mutation (NCI-H460. A549, and NCIH441) (Figure 1). In lung cancer cells with EGFR mutation, $H B E G F$ exhibited the highest expression of the EGFR ligands examined. These results suggest that lung cancer cells with EGFR mutation have characteristics of enhanced expression of EGFR and EGFR ligands.

Response to gefitinib. With the aim of investigating the response of lung cancer cells to gefitinib, we evaluated the 


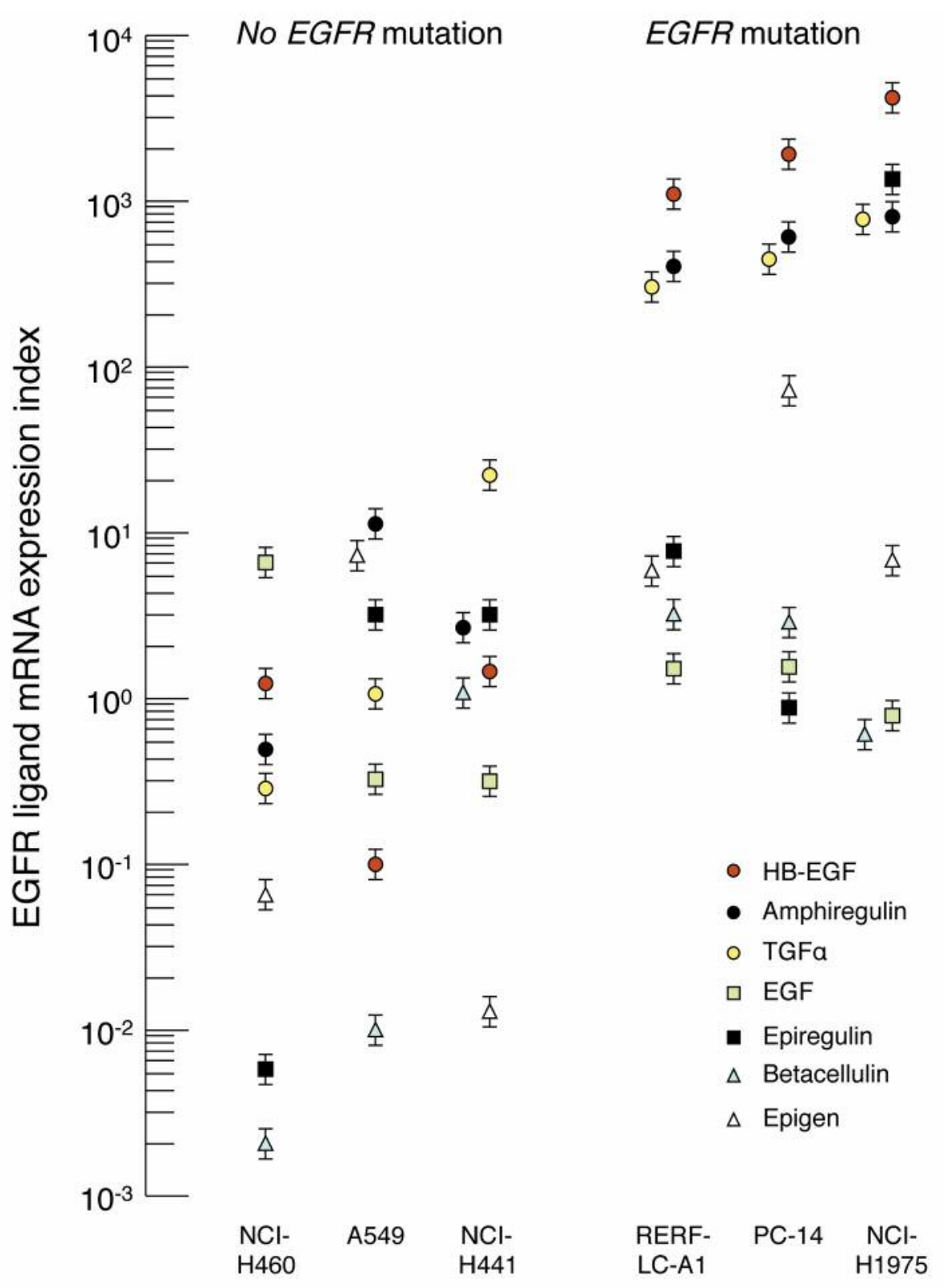

Figure 1. Characterization of lung cancer cells. The mRNA expression indices of epidermal growth factor receptor (EGFR) ligands in lung cancer cell lines harboring wild-type or mutant EGFR were determined by real-time polymerase chain reaction. Data represent the means $\pm S E M$ of the mRNA expression indices for each EGFR ligand. HB-EGF: Heparin-binding EGF-like growth factor; TGF : transforming growth factor alpha.

apoptotic rate in each cell line after incubation with different concentrations of gefitinib. NCI-H460. A549, and NCIH1975 cells exhibited little response to gefitinib, even at high concentrations. In RERF-LC-A1 cells, a significant dose-dependent increase in apoptosis was observed following treatment with gefitinib (Figure 2). These results suggest that lung cancer cells with EGFR mutation at L858R, such as RERF-LC-A1, are remarkably sensitive to gefitinib, and that lung cancer cells with double mutations at L858R and T790M, such as NCI-H1975, are relatively insensitive to gefitinib.

In vitro and in vivo response to CRM197 in lung cancer cell lines with EGFR mutation. We assessed the antitumor effects of CRM197 on lung cancer cell lines with EGFR mutation by analyzing cell apoptosis in vitro and 


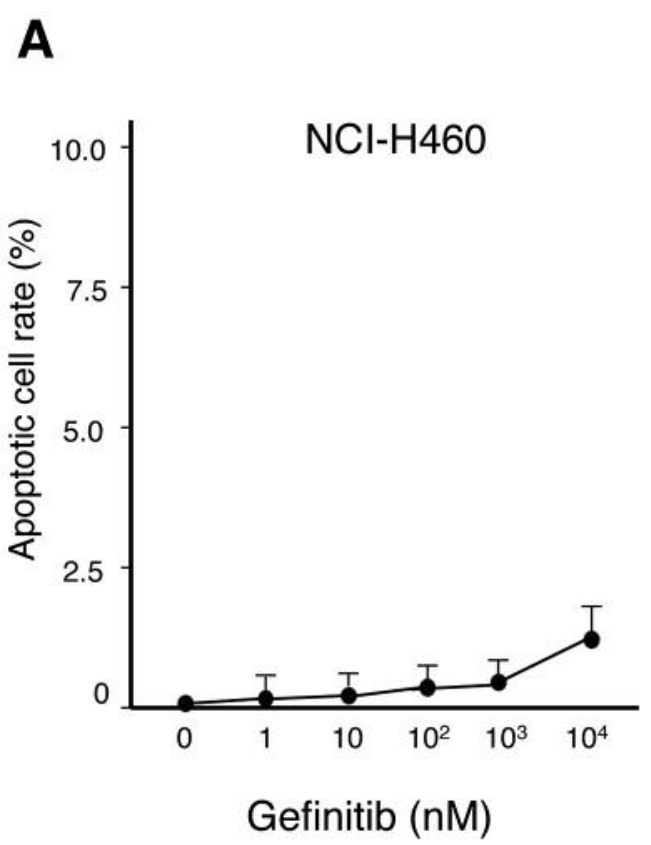

B
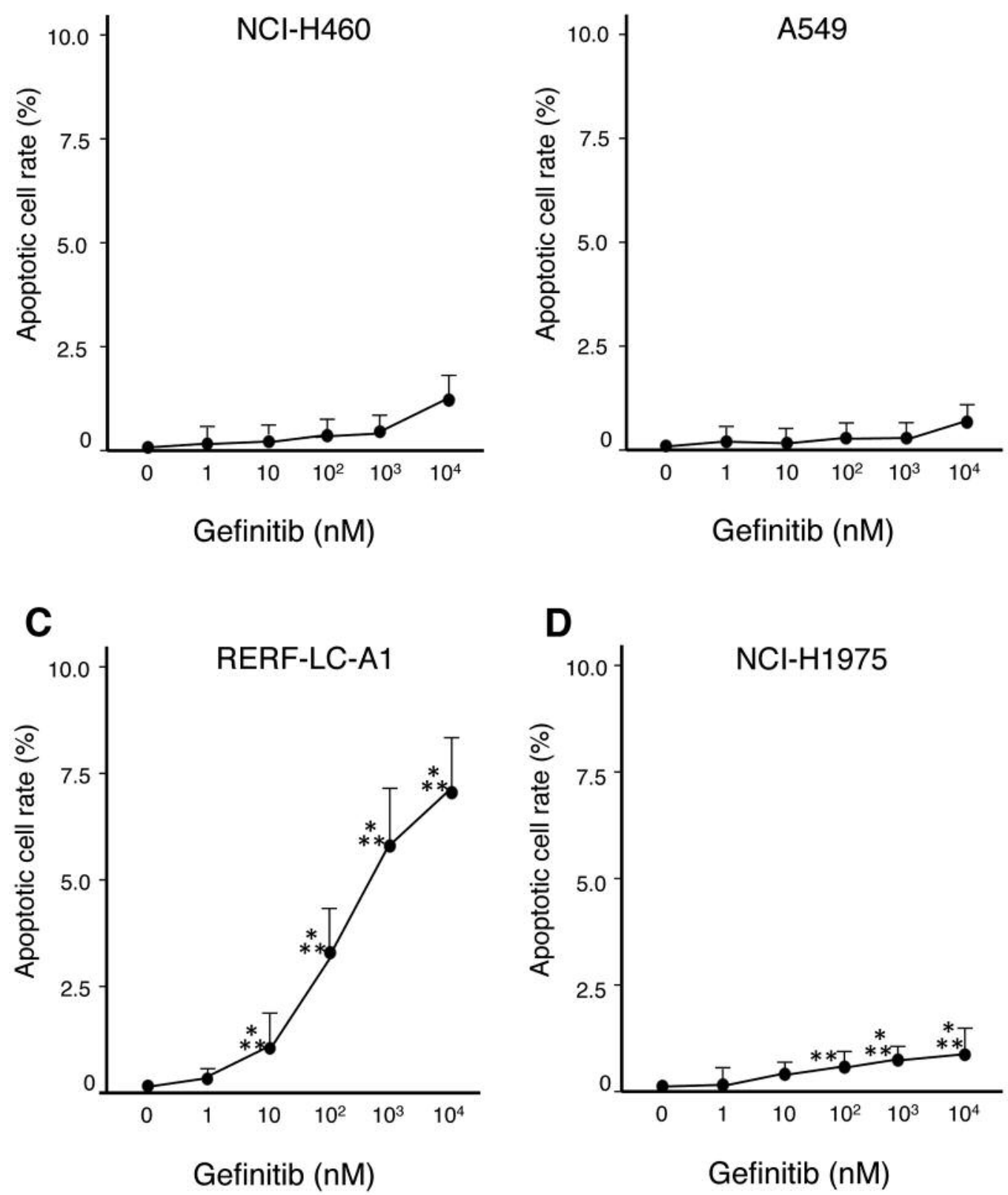

Figure 2. Response of lung cancer cells to gefitinib. Apoptosis rates in lung cancer cells after treatment with different concentrations of gefitinib. NCI-H460 and A549, no epidermal growth factor receptor (EGFR) mutation; RERF-LC-A1, single EGFR mutation; NCI-H1975, double EGFR mutation. Data represent the means \pm SEM of apoptosis rates in lung cancer cell lines. ${ }^{*} p<0.05$ versus NCI-H460 cells. **p<0.05 versus A549 cells.

tumorigenicity in vivo. RERF-LC-A1 and NCI-H1975 cells exhibited apoptotic rates of $4.43 \%$ and $7.46 \%$, respectively, following treatment with CRM197 (Figure 3). In addition, tumor formation by RERF-LC-A1 cells was completely suppressed, and that by NCI-H1975 was also markedly inhibited (Figure 4). These results suggested that HB-EGF is a rational target for lung cancer with single and double mutations of EGFR, and that CRM197 is a potential molecularly-targeted agent for lung cancer with secondary mutation of T790M EGFR. 


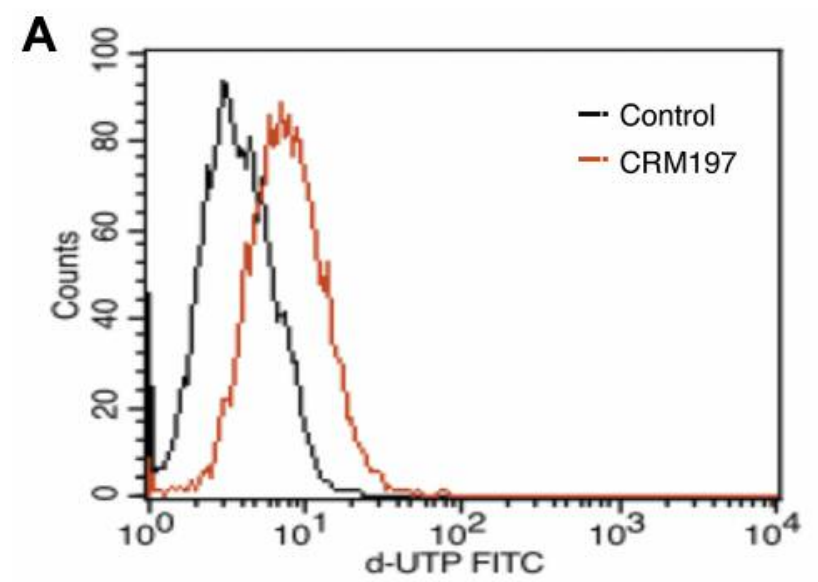

B

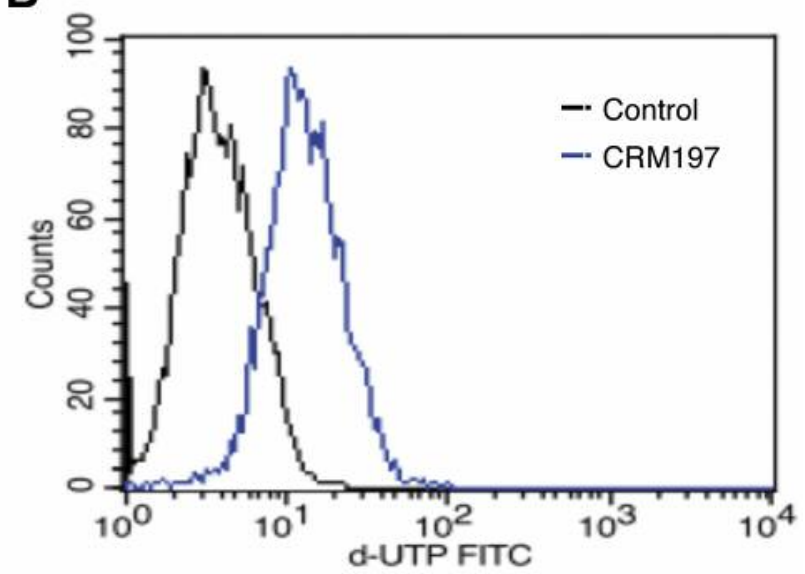

Figure 3. In vitro response to cross-reacting material 197 (CRM197). The antitumor effect of CRM197 against lung cancer cell lines with epidermal growth factor receptor (EGFR) mutation in vitro. RERF-LC-Al (A) and NCI-H1975 (B) cells demonstrated apoptotic rates of $4.43 \%$ and $7.46 \%$, respectively, after CRM197 treatment. d-UTP: 2'-Deoxyuridine 5'triphosphate; FITC: fluorescein sothiocyanate isomer-I.

\section{Discussion}

The expression of EGFR ligands, especially HB-EGF, was remarkably enhanced in lung cancer cell lines with EGFR mutation compared to those without EGFR mutation. HBEGF was identified as a promising therapeutic target in lung cancer with single as well as double mutations of EGFR.

The tyrosine kinase function of EGFR is encoded by exons $18-24$, in which the majority of patients with NSCLC patients with $E G F R$ defects have mutations (6). Following the occurrence of mutations in exons 18-24, signaling between EGFR and its downstream molecules may be continuously activated, and may lead to enhancement of the
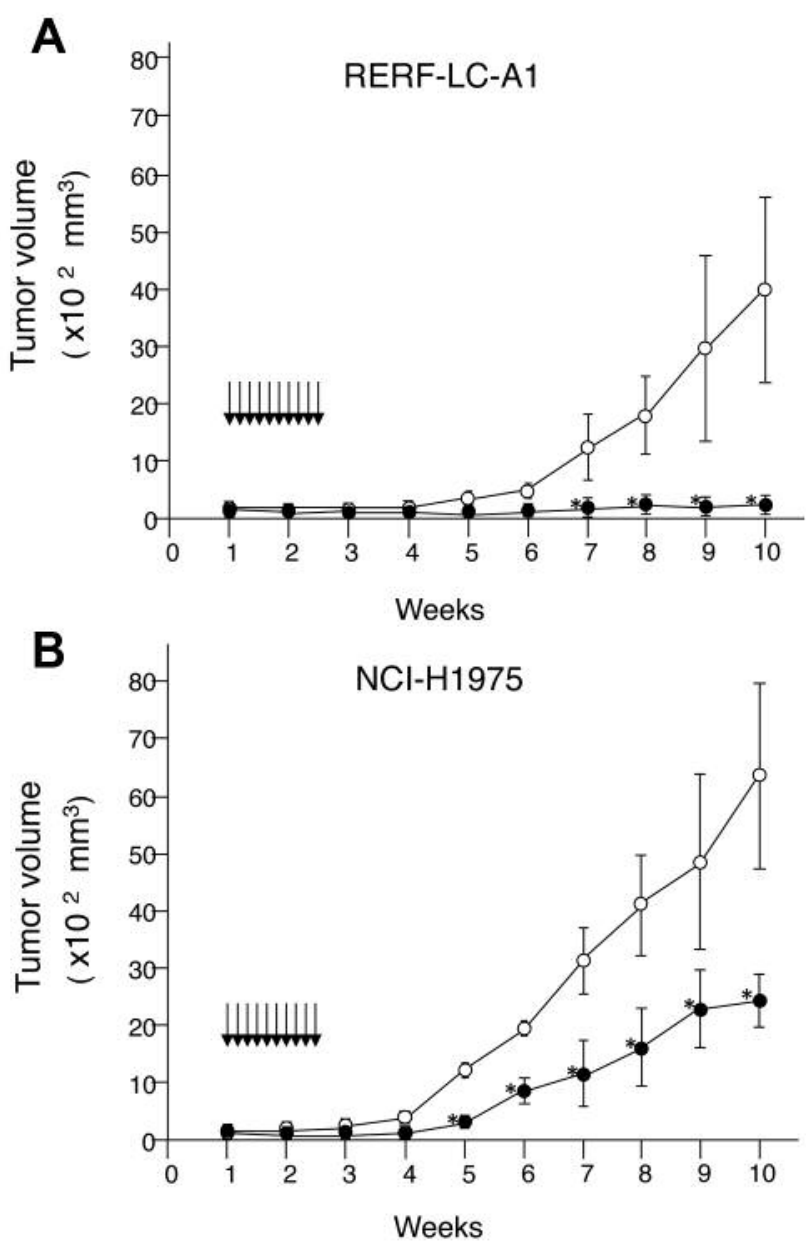

Figure 4. In vivo response to cross-reacting material 197 (CRM197). Weekly alterations in growth of tumor derived from RERF-LC-A1 (A) and NCI-H1975 (B) cells in NOD/SCID mice $(n=10)$. CRM197 (1 mg/day) was injected intraperitoneally every day for 10 days once tumor volume exceeded $100 \mathrm{~mm}^{3}$. Arrows indicate the days on which CRM197 was administered. Data represent the means \pm SEM of tumor volumes. ${ }^{*} p<0.05$ versus control mice without CRM197 treatment.

autocrine amplification loop between EGFR and its ligands. Therefore, it is plausible that the markedly activated signal of the EGFR pathway may induce the expression of EGFR ligands in lung cancer with EGFR mutation. In mouse fibroblasts, the transfection of $E G F R$, human EGFR2 (HER2), or $A K T$ up-regulates the expression of HB-EGF, accompanied by activation of downstream EGFR pathways (16). Resistance to EGFR TKIs is inevitable because of a variety of mechanisms including the secondary mutation of EGFR (T790M), aberrations in the downstream EGFR pathways such as KRAS mutation and loss of PTEN, and the activation of alternative pathways $(17,18)$. According to these lines of evidence, the predominant expression of 
HB-EGF in lung cancer with EGFR mutation might be linked to the activation of EGFR signaling.

The majority of patients with lung cancer with EGFR mutations who are treated with first-generation TKIs such as gefitinib or erlotinib acquire secondary EGFR mutation (T790M) as a resistance mechanism to these TKIs within 8 to 16 months (6). Novel molecularly-targeted agents against lung cancer with $E G F R^{T 790 M}$ have been developed as thirdgeneration TKIs $(19,20)$. However, it is likely that resistance to these third-generation TKIs may emerge as a result of further additional EGFR mutations. Cetuximab, a monoclonal antibody to EGFR, has been used predominantly in combination with EGFR TKIs against TKI-resistant tumors. In 126 patients with NSCLC whose disease had progressed during treatment with erlotinib or gefitinib, the combination of afatinib and cetuximab demonstrated little difference in progression-free survival between patients with and without $E G F R^{T 790 M}$ (21). In addition, the combination of erlotinib and cetuximab indicated no clinical response in patients with resistance to erlotinib in a phase I/II study (22). In principle, cetuximab binds to the extracellular domain of EGFR and prevents ligand-dependent receptor activation. However, cetuximab can block the homodimerization of EGFR but not the heterodimerization of EGFR and other HER receptors, hence cetuximab does not suppress AKT signaling in cancer cells (16). Conversely, the blockage of HB-EGF can inhibit both HB-EGF-dependent homodimerization and heterodimerization, demonstrating that an inhibitor of HBEGF suppresses AKT signaling as well as ERK. CRM197, an inhibitor of HB-EGF, and an anticancer agent with a high molecular weight, was shown to be clinically safe and effective for patients with ovarian cancer (23). The combination of TKIs and CRM197 may be a potential treatment for patients with NSCLC with EGFR mutation.

In conclusion, HB-EGF may also be a rational target for lung cancer with resistance to TKIs because of EGFR downstream aberrations. CRM197 might be expected to improve prognosis in patients with NSCLC with EGFR mutation.

\section{Conflicts of Interest}

The Authors have no potential conflicts of interest in regard to this study.

\section{Acknowledgements}

This work was supported in part by a Grant-in-Aid for challenging Exploratory Research (no. 26670731), Scientific Research (B) (no. 26293362), and fund from the Central Research Institute of Fukuoka University ; The Center for Advanced Molecular Medicine, Fukuoka University from the Ministry of Education, Culture, Sports, Science and Technology (Tokyo, Japan); a Grant-in-Aid from the Kakihara Science and Technology Foundation (Fukuoka, Japan), and Kyowa Hakko Kirin Co. Ltd. (Tokyo, Japan) to S. Miyamoto.

\section{References}

1 Ho C, Ramsden K, Zhai Y, Murray N, Sun S, Melosky B and Laskin J: Less toxic chemotherapy improves uptake of all lines of chemotherapy in advanced non-small-cell lung cancer: a 10year retrospective population-based review. J Thorac Oncol 9: 1180-1186, 2014.

2 American Cancer Society. Lung Cancer (Non-Small Cell). Updated March 4, 2015. Accessed May 19, 2015. Available : http:// www.cancer.org/cancer/lungcancernon-smallcell/detailedguide/nonsmall-cell-lung-cancersurvival-rates.

3 Rosell R, Carcereny E, Gervais R, Vergenegre A, Massuti B, Felip E, Palmero R, Garcia-Gomez R and Pallares C, Sanchez JM, Porta R, Cobo M, Garrido P, Longo F, Moran T, Insa A, De Marinis F, Corre R, Bover I, Lliano A, Dansin E, de Castro J, Milella M, Reguart N, Altavilla G, Jimenez U, Provencio M, Moreno MA, Terrasa J, Munoz-Langa J, Valdivia J, Isla D, Domine M, Molinier O, Mazieres J, Baize N, Garcia-Campelo R, Robinet G, Rodriguez-Abreu D, Lopez-Vivanco G, Gebbia V, Ferrera-Delgado L, Bombaron P, Bemabe R, Bearz A, Artal A,Cortesi E, Rolfo C, Sanchez-Ronco M, Drozdowskyi A, Queralt C, de Aquirre I, Ramirez JL, Sanchez JJ, Molina MA, Taron $M$ and Paz-Ares L: Erlotinib versus standard chemotherapy as first-line treatment for European patients with advanced EGFR mutation-positive non-small-cell lung cancer (EURTAC): a multicentre, open-label, randomized phase 3 trial. Lancet Oncol 13: 239-246, 2012.

4 Sequist LV, Yang JC, Yamamoto N, O’Byme K, Hirsh V, Mork T, Geater SL, Orlov S, Tsai CM, Boyer M, Su WC, Bennouna J, Kato T, Gorbunova V, Lee KH, Shah R, Massey D, Zazulina V, Shahidi M and Schuler M: Phase III study of afatinib or cisplatin plus pemetrexed in patients with metastatic lung adenocarcinoma with EGFR mutations. J Clin Oncol 31: 33273334, 2013.

5 Langer CJ: Epidermal growth factor receptor inhibition in mutation-positive non-small-cell lung cancer: Is afatinib better or simply newer? J Clin Oncol 31: 3303-3306, 2013.

6 Yu HA, Arcila ME, Rekhtman N, Sima CS, Zakowski MF, Pao W, Kris MG, Miller VA, Ladanyi M and Riely GJ: Analysis of tumor specimens at the time of acquired resistance to EGFR-TKI therapy in 155 patients with EGFR-mutant lung cancers. Clin Cancer Res 19: 2240-2247, 2013.

7 Miyamoto S, Yagi H, Yotsumoto F, Kawarabayashi T and Mekada E: Heparin-binding epidermal growth factor-like growth factor as a novel targeting molecule for cancer therapy. Cancer Sci 97: 341-347, 2006.

8 Miyamoto S, Yagi H, Yotsumoto F, Horiuchi S, Yoshizato T, Kawarabayashi T, Kuroki M and Mekada E: New approach to cancer therapy: heparin binding-epidermal growth factor-like growth factor as a novel targeting molecule. Anticancer Res 27: 3713-3721, 2007.

9 Miyamoto S, Yagi H, Yotsumoto F, Kawarabayashi $\mathrm{T}$ and Mekada E: Heparin-binding epidermal growth factor-like growth factor as a new target molecule for cancer therapy. Adv Exp Med Biol 622: 281-295, 2008.

10 Miyamoto S, Hirata M, Yamazaki A, Kageyama T, Hasuwa H, Mizushima H, Tanaka Y, Yagi H, Sonoda K, Kai M, Kanoh H, Nakano H and Mekada E: Heparin-binding EGF-like growth factor is a promising target for ovarian cancer therapy. Cancer Res 64: 5720-7572, 2004. 
11 Yotsumoto F, Yagi H, Suzuki SO, Oki E, Tsujioka H, Hachisuga T, Sonoda K, Kawarabayashi T, Mekada E and Miyamoto S: Validation of HB-EGF and amphiregulin as targets for human cancer therapy. Biochem Biophys Res Commun 365: 555-561, 2008.

12 Sanui A, Yotsumoto F, Tsujioka H, Fukami T, Horiuchi S, Shirota K, Yoshizato T, Kawarabayashi T, Kuroki $M$ and Miyamoto S: HB-EGF inhibition in combination with various anticancer agents enhances its antitumor effects in gastric cancer. Anticancer Res 30: 3143-3149, 2010.

13 Tanaka Y, Miyamoto S, Suzuki SO, Oki E, Yagi H, Sonoda K, Yamazaki A, Mizushima H, Maehara Y, Mekada E and Nakano $\mathrm{H}$ : Clinical significance of heparin-binding epidermal growth factor-like growth factor and a disintegrin and metalloprotease 17 expression in human ovarian cancer. Clin Cancer Res 11: 4783-4792, 2005.

14 Miyamoto S, Akiyama SK and Yamada KM: Synergistic roles for receptor occupancy and aggregation in integrin transmembrane function. Science 267: 883-885, 1995.

15 Bissery MC, Guenard D, Gueritte-Voegelein F and Lavelle F: Experimetal antitumor activity of taxotere (RP 56976, NSC 628503), a Taxol analogue. Cancer Res 51: 4845-4852, 1991.

16 Yotsumoto F, Oki E, Tokunaga E, Maehara Y, Kuroki M and Miyamoto S: HB-EGF orchestrates the complex signals involved in triple-negative and trastuzumab-resistant breast cancer. Int $\mathbf{J}$ Cancer 127: 2707-2717, 2010.

17 Huang L and Fu L: Mechanisms of resistance to EGFR tyrosine kinase inhibitors. Acta Pharm Sin B 5: 390-401, 2015.

18 Zhou C and Yao LD: Strategies to improve outcomes of patients with $E G F R$-mutant non-small cell lung cancer: Review of the literature. J Thorac Oncol 11: 174-186, 2016.

19 Jänne PA, Yang JC, Kim DW, Planchard D, Ohe Y, Ramalingam SS, Ahn MJ, Kim SW, Su WC, Horn L, Haggstrom D, Felip E, Kim JH, Frewer P, Cantarini M, Brown KH, Dickinson PA, Ghiorghiu S and Ranson M: AZD9291 in EGFR inhibitorresistant non-small-cell lung cancer. N Engl J Med 372: 1689$1699,2015$.
20 Sequist LV, Soria JC, Goldman JW, Wakelee HA, Gadgeel SM, Varga A, Papadimitrakopoulou V, Solomon BJ, Oxnard GR, Dziadziuszko R, Aisner DL, Doebele RC, Galasso C, Garon EB, Heist RS, Logan J, Neal JW, Mendenhall MA, Nichols S, Piotrowska Z, Wozniak AJ, Raponi M, Karlovich CA, Jaw-Tsai S, Isaacson J, Despain D, Matheny SL, Rolfe L, Allen AR and Camidge DR: Rociletinib in EGFR-mutated non-small-cell lung cancer. N Engl J Med 372: 1700-1709, 2015.

21 Janjigian YY, Smit EF, Groen HJ, Horn L, Gettinger S, Camidge DR, Riely GJ, Wang B, Fu Y, Chand VK, Miller VA and Pao W: Dual inhibition of EGFR with afatinib and cetuximab in kinase inhibitor-resistant EGFR-mutant lung cancer with and without T790M mutations. Cancer Discov 4: 1036-1045, 2014.

22 Janjigian YY, Azzoli CG, Krug LM, Pereira LK, Rizvi NA, Pietanza MC, Kris MG, Ginsberg MS, Pao W, Miller VA and Riely GJ: Phase I/II trial of cetuximab and erlotinib in patients with lung adenocarcinoma and acquired resistance to erlotinib. Clin Cancer Res 17: 2521-2527, 2011.

23 Miyamoto S, Yotsumoto F, Ueda T, Fukami T, Sanui A, Miyata K, Nam SO, Fukagawa S, Katsuta T, Maehara M, Kondo H, Miyahara D, Shirota K, Yoshizato T, Kuroki M, Nishikawa H, Saku K, Tsuboi Y, Ishitsuka K, Takamatsu Y, Tamura K, Matsunaga A, Hachisuga T, Nishino S, Odawara T, Maeda K, Manabe S, Ishikawa T, Okuno Y, Ohishi M, Hikita T, Mizushima $\mathrm{H}$, Iwamoto R and Mekada E: BK-UM in patients with recurrent ovarian cancer or peritoneal cancer: a first-in-human phase-I study. BMC Cancer 17: 89, 2017.
Received May 2, 2017

Revised May 29, 2017

Accepted May 30, 2017 